\title{
MODEL DISTRIBUSI BAHAN AJAR UNIVERSITAS TERBUKA DAN IMPLEMENTASINYA
}

\author{
Sitta Alief Farihati (sitta@mail.ut.ac.id) \\ Universitas Terbuka \\ Amril Aman \\ I. N. Kutha Ardana \\ Pascasarjana Institut Pertanian Bogor
}

\begin{abstract}
Universitas Terbuka (UT) was implementing the centralized distribution of learning material, it is not considered efficient. Therefore, the decentralized distribution system which requires warehouses at certain regional offices will be proposed. The aims of this research are (1) investigating the decentralized learning material distribution model, (2) choosing the optimal location of warehouses to minimize the cost of learning material distribution, (3) choosing the regional offices which will be served optimally by each warehouse, (4) comparing efficiency of the centralized and decentralized learning material distribution system. The distribution problem is modeled as a linear mixed integer programming problem. The model will be solved using Branch and Bound method. This study considers centralized learning material distribution system and two alternative of decentralized learning material distribution systems, which are alternative 1 and alternative 2. It is found that in 2008 the cost of the alternative 2 is lower than the centralized learning distribution system. Besides, if the demand of learning material is increasing, the alternative 2 is still less costly than the other systems.
\end{abstract}

Key words : centralized learning material distribution, decentralized learning material distribution, model, warehouses.

Persediaan bahan ajar UT di UPBJJ-UT terkait dengan sistem distribusi bahan ajar UT. Sampai saat ini UT melaksanakan sistem distribusi bahan ajar terpusat. Sistem tersebut menempatkan Kantor Pusat UT sebagai pusat penerbitan dan pusat pendistribusian bahan ajar. Untuk penerbitan bahan ajar, UT melibatkan perusahaan percetakan subkontrak. Bahan ajar tercetak yang belum dikirim akan disimpan terlebih dahulu di gudang Kantor Pusat UT. Dalam hal pendistribusian bahan ajar, Kantor Pusat UT akan mengirim bahan ajar setelah adanya permintaan dari UPBJJ-UT dan pengiriman dilakukan oleh perusahaan pengiriman subkontrak langsung dari Kantor Pusat UT menuju UPBJJ-UT bersangkutan. Distribusi bahan ajar dengan cara tersebut mengakibatkan pengiriman bahan ajar sering dilakukan setiap hari kerja dalam kapasitas pengangkutan sedikit. Akibatnya pelaksanaan distribusi secara terpusat tersebut tidak efisien (Sitta, 2009).

Menurut Pratmoko (2002), sistem distribusi bahan ajar terpusat perlu diubah menjadi sistem distribusi bahan ajar tidak terpusat. Dalam artikelnya, Pratmoko menyusun sistem distribusi bahan ajar tidak terpusat dengan menempatkan percetakan pada UPBJJ-UT tertentu sebagai penyuplai bahan ajar ke UPBJJ-UT terdekat. Dalam penelitian ini, akan dikaji sistem distribusi bahan ajar tidak 
terpusat yang menempatkan gudang di UPBJJ-UT tertentu sebagai lokasi penyimpanan sementara dan penyuplai bahan ajar.

Penelitian ini bertujuan untuk (1) menentukan model distribusi bahan ajar tidak terpusat yang menempatkan gudang antara Kantor Pusat UT dengan UPBJJ-UT di seluruh Indonesia, (2) menentukan lokasi gudang antara Kantor Pusat UT ke UPBJJ-UT di seluruh Indonesia yang meminimalkan biaya distribusi bahan ajar, (3) menentukan UPBJJ-UT yang disuplai oleh setiap gudang dan (4) membandingkan efisiensi antara sistem distribusi bahan ajar tidak terpusat dengan sistem distribusi bahan ajar terpusat.

\section{METODOLOGI}

Penelitian ini dibagi menjadi empat tahap, yaitu (1) pendeskripsian dan formulasi masalah, (2) pemodelan, (3) solusi model dan (4) implementasi model. Pada tahap pemodelan, masalah distribusi dimodelkan sebagai masalah linear mixed integer programming. Model tersebut kemudian diselesaikan dengan menggunakan metode Branch and Bound dengan bantuan software Lingo 8.0. Implementasi model dilakukan dengan cara menyimulasikan model dengan menggunakan data koordinat geografi bumi, data perkiraan permintaan bahan ajar Pendidikan Dasar (Pendas) UT dan data biaya pengiriman berdasarkan subkontrak tahun 2008.

\section{HASIL DAN PEMBAHASAN}

\section{Deskripsi Masalah}

Sistem Distribusi Bahan Ajar Terpusat

Sistem distribusi bahan ajar terpusat menempatkan Kantor Pusat UT sebagai pusat produksi dan pemasok utama bahan ajar ke UPBJJ-UT di seluruh Indonesia. Sistem distribusi terpusat memberlakukan pengiriman dari Kantor Pusat UT langsung ke UPBJJ-UT. Biasanya UPBJJ-UT mengajukan permintaan ke Kantor Pusat UT minimal 2 kali dalam setahun karena terdapat 2 masa registrasi dalam setahun untuk Program Pendas.

\section{Sistem Distribusi Bahan Ajar Tidak Terpusat Alternatif 1}

Jika percetakan terpusat di Kantor Pusat UT, maka ditempatkan gudang-gudang yang berfungsi sebagai lokasi penyimpanan dan pemasok bahan ajar ke UPBJJ-UT terdekat. Gudanggudang tersebut akan menempati lokasi yang sama dengan UPBJJ-UT yang terpilih.

Pada sistem ini, percetakan bahan ajar terpusat di Kantor Pusat UT sehingga di Kantor Pusat UT terdapat gudang utama yang akan memasok gudang-gudang di UPBJJ-UT terpilih. Gudang utama hanya akan memasok gudang di UPBJJ-UT terpilih dan jumlah gudang yang akan dipasok oleh gudang utama lebih dari satu.

\section{Sistem Distribusi Bahan Ajar Tidak Terpusat Alternatif 2}

Jika percetakan tidak terpusat di Kantor Pusat UT, maka ditempatkan percetakan dan gudang yang berfungsi sebagai lokasi penyimpanan dan pemasok bahan ajar ke UPBJJ-UT terdekat. Percetakan dan gudang akan menempati lokasi yang sama dengan UPBJJ-UT yang terpilih.

Sistem ini menempatkan percetakan bahan ajar tidak saja di Kantor Pusat UT namun juga di UPBJJ-UT terpilih, sehingga gudang Kantor Pusat UT sama kedudukannya dengan gudang di 
UPBJJ-UT terpilih. Gudang di Kantor Pusat UT akan memasok UPBJJ-UT yang terdekat, begitu pula gudang di UPBJJ-UT terpilih akan memasok UPBJJ-UT terdekat.

Pada kedua sistem distribusi bahan ajar tidak terpusat, UPBJJ-UT yang ditempati sebagai gudang juga akan menerima pasokan bahan ajar dari gudang tersebut, sehingga biaya transportasi bahan ajar sama dengan nol. Setiap UPBJJ-UT hanya akan dipasok oleh satu gudang. Jumlah seluruh UPBJJ-UT yang dipasok sama dengan 37 , hal ini sesuai dengan jumlah seluruh UPBJJ-UT yang ada.

Bahan ajar akan dikirim melalui transportasi darat, laut dan udara. Penentuan penggunaan transportasi dipertimbangkan berdasarkan kapasitas kendaraan, hal ini disebabkan bahan ajar merupakan produk yang tahan lama sehingga tidak perlu dipertimbangkan lama waktu perjalanan.

\section{Formulasi Masalah}

Tujuan utama masalah distribusi bahan ajar adalah meminimalkan biaya distribusi. Dalam pemodelan, biaya percetakan dan biaya penggudangan di gudang utama diabaikan karena komponen biaya distribusi hanya meliputi biaya pengiriman, biaya penggudangan dan biaya penalti, seperti yang dinyatakan oleh Kotler, Ang, Leong \& Tan (2002). Namun, saat membandingkan efisiensi antara ketiga sistem, biaya percetakan dan biaya penggudangan di gudang utama diperhitungkan. Hal ini bertujuan untuk menghitung keseluruhan biaya operasional setiap sistem distribusi.

Diberikan asumsi-asumsi berikut :

1. Setiap UPBJJ-UT dan gudang mempunyai permintaan

2. Jumlah permintaan setiap UPBJJ-UT dan gudang tetap

3. Jumlah permintaan setiap UPBJJ-UT, kapasitas setiap gudang dan kapasitas setiap jenis kendaraan pengangkut diketahui

4. Setiap kendaraan hanya melewati satu rute

5. Total biaya transportasi dari setiap jenis kendaraan diketahui, biaya tersebut termasuk biaya perjalanan kembali dari tujuan ke sumber

6. Biaya transportasi setiap jenis kendaraan meliputi biaya bongkar muat dan biaya penyewaan gudang

7. Biaya pembuatan gudang baru dan biaya operasional gudang baru dalam satu tahun diketahui

8. Biaya operasional gudang utama diabaikan

9. Biaya percetakan bahan ajar diabaikan.

\section{Model}

Setiap sistem distribusi bahan ajar akan disusun dalam suatu model yang terdiri dari batasan-batasan (constraints). Model I merupakan pemodelan sistem distribusi bahan ajar terpusat, model II merupakan pemodelan sistem distribusi bahan ajar tidak terpusat alternatif 1 , dan model III merupakan pemodelan sistem distribusi bahan ajar tidak terpusat alternatif 2. Ketiga model menggunakan variabel dan parameter yang sama. 
Didefinisikan :

$I=\{0,1, \ldots, i, \ldots, n\} ; n \leq 37$ adalah himpunan indeks yang menyatakan lokasi gudang, dengan $i=0$ adalah indeks gudang utama di Kantor Pusat UT $J=\{1, \ldots, j, \ldots, 37\}$ adalah himpunan indeks yang menyatakan lokasi konsumen $K=\left\{1, \ldots, k, \ldots, k^{\prime}\right\}$ adalah himpunan indeks yang menyatakan jenis kendaraan

Variabel dan parameter yang digunakan adalah :

$a_{i j}=$ jumlah bahan ajar yang dikirim dari gudang $i$ ke konsumen $j, a_{i j} \in \square^{+}$

$q_{j}=$ jumlah permintaan bahan ajar per tahun setiap konsumen $j, q_{j} \in \square^{+}$

Cap = kapasitas gudang, Cap $\in \square^{+}$

$Q_{k}=$ kapasitas kendaraan jenis $k, Q_{k} \in \square^{+}$

$f=$ biaya penggudangan,$f \in \square^{+}$

$\lambda=$ biaya penalti bahan ajar yang tidak dikirim (tersisa di gudang), $\lambda \in \square^{+}, \lambda>0$

$M=$ jumlah minimal bahan ajar yang dikirim per tahun, $M \in \square^{+}$

$v_{i}=$ jumlah bahan ajar yang dikirim dari gudang $i, v_{i} \in \square^{+}$

$c_{i j}^{k}=$ biaya transportasi dari gudang $i$ ke konsumen $j$ menggunakan kendaraan $k$, $c_{i j}^{k} \in \square^{+}$

$w_{i j}=$ frekuensi pengiriman per tahun dari gudang $i$ ke konsumen $j, w_{i j} \in \square^{+}$

$\gamma_{k}=$ konstanta biaya untuk setiap kendaraan jenis $k, \gamma_{k} \in \square^{+}$

$d_{i j}=$ jarak (pada permukaan bumi) antara gudang $i$ dan konsumen $j$, jika titik koordinat gudang/konsumen pada sistem koordinat geografi adalah $(\alpha, \beta), \alpha$ koordinat lintang dan $\beta$ koordinat bujur, maka

$$
d_{i j}=\cos ^{-1}\left(\sin \beta_{i} \sin \beta_{j}+\cos \beta_{i} \cos \beta_{j} \cos \left|\alpha_{i}-\alpha_{j}\right|\right), d_{i j} \in \square^{+} \text {(Chang, 2004). }
$$

Variabel keputusan yang digunakan untuk menentukan terpilih tidaknya UPBJJ-UT sebagai gudang adalah :

$x_{i}=\left\{\begin{array}{lc}1, & \text { jika gudang ditempatkan di } i \\ 0, & \text { selainnya }\end{array}\right.$

Selain itu diperlukan pula variabel keputusan untuk menentukan kendaraan yang digunakan sebagai alat transportasi pengiriman yaitu :

$y_{i j}^{k}=\left\{\begin{array}{lc}1, & \text { jika kendaraan jenis } k \text { digunakan dari gudang } i \text { ke konsumen } j \\ 0, & \text { selainnya }\end{array}\right.$ 


\section{Model I} konsumen.

Diasumsikan stok bahan ajar di gudang utama tersedia sebesar permintaan seluruh Fungsi objektifnya adalah :

Minimumkan $\quad \sum_{j=1}^{37} \sum_{k=1}^{k^{\prime}} y_{0 j}^{k} c_{0 j}^{k} a_{0 j}$

Fungsi $\sum_{j=1}^{37} \sum_{k=1}^{k^{\prime}} y_{0 j}^{k} c_{0 j}^{k} a_{0 j}$ menyatakan jumlah biaya pengiriman dari gudang utama ke konsumen.

Batasan yang digunakan adalah :

1. Satu kali pengiriman bahan ajar tidak lebih dari permintaan konsumen

$w_{0 j} M \geq q_{j}$ untuk $j \in J$

Kendala ini untuk menentukan frekuensi pengiriman bahan ajar ke setiap konsumen.

2. Pengiriman bahan ajar ke konsumen dilakukan minimal dua kali dalam setahun

$w_{0 j} \geq 2$ untuk $j \in J$

Kendala ini untuk menentukan frekuensi pengiriman bahan ajar ke setiap konsumen minimal dua kali dalam setahun.

3. Jumlah bahan ajar yang disuplai sama dengan jumlah permintaan bahan ajar $w_{0 j} a_{0 j}=q_{j}$ untuk $j \in J$

Kendala ini untuk memastikan setiap permintaan konsumen dipenuhi .

4. Setiap gudang dan konsumen dapat dilayani dengan kendaraan jenis $k$ $y_{0 j}^{k} a_{0 j} \leq Q_{k}$ untuk $k \in K ; j \in J$

Kendala ini untuk menentukan jenis kendaraan yang akan mengirim bahan ajar dari gudang utama ke konsumen berdasarkan kapasitas kendaraan.

5. Setiap konsumen hanya disuplai oleh satu kendaraan jenis $k$

$$
\sum_{i=1}^{n} \sum_{k=1}^{k^{\prime}} y_{0 j}^{k}=1
$$

untuk $j \in J$

Kendala ini untuk memastikan kendaraan yang akan mengirim bahan ajar dari gudang utama ke setiap konsumen hanya satu jenis.

6. Hubungan antara biaya transportasi dan jarak

$c_{0 j}^{k}=\gamma_{k} d_{0 j}$ untuk $k \in K ; j \in J$

Kendala ini untuk menentukan biaya transportasi setiap jenis kendaraan dari gudang utama ke konsumen. 
Pada model II dan model III, diasumsikan stok bahan ajar di gudang utama tersedia sebanyak permintaan seluruh gudang terpilih model II.

Model II

Diasumsikan stok bahan ajar di gudang terpilih sama dengan nol.

Fungsi objektifnya adalah :

Minimumkan $\sum_{i=1}^{n} \sum_{k=1}^{k^{\prime}} y_{0 i}^{k} c_{0 i}^{k} C a p+\sum_{i=1}^{n} \sum_{j=1}^{37} \sum_{k=1}^{k^{\prime}} y_{i j}^{k} c_{i j}^{k} a_{i j}+\sum_{i=1}^{n} x_{i} f+\lambda \sum_{i=1}^{n}\left(x_{i}\right.$ Cap $\left.-v_{i}\right)$

Fungsi $\sum_{i=1}^{n} \sum_{k=1}^{k^{\prime}} y_{0 i}^{k} c_{0 i}^{k}$ Cap menyatakan jumlah biaya pengiriman dari gudang utama ke gudang terpilih. Fungsi $\sum_{i=1}^{n} \sum_{j=1}^{37} \sum_{k=1}^{k^{\prime}} y_{i j}^{k} c_{i j}^{k} a_{i j}$ menyatakan jumlah biaya pengiriman dari gudang terpilih ke konsumen. Fungsi $\sum_{i=1}^{n} x_{i} f$ menyatakan jumlah biaya penggudangan di gudang terpilih. Fungsi $\lambda \sum_{i=1}^{n}\left(x_{i}\right.$ Cap $\left.-v_{i}\right)$ menyatakan jumlah biaya penalti di gudang terpilih.

Batasan yang digunakan adalah :

1. Satu kali pengiriman bahan ajar tidak lebih dari permintaan konsumen $w_{i j} M \geq q_{j}$ untuk $i \in(I-\{0\}) ; j \in J$

2. Pengiriman bahan ajar ke konsumen dilakukan minimal dua kali dalam setahun $w_{i j} \geq 2$ untuk $i \in(I-\{0\}) ; j \in J$

3. Jumlah bahan ajar yang disuplai gudang sama dengan jumlah permintaan konsumen $w_{i j} a_{i j}=q_{j}$ untuk $i \in(I-\{0\}) ; j \in J$

4. Setiap gudang dan konsumen dapat dilayani dengan kendaraan jenis $k$

$y_{0 i}^{k}$ Cap $\leq Q_{k}$ untuk $k \in K, i \in(I-\{0\})$

$y_{i j}^{k} a_{i j} \leq Q_{k}$ untuk $k \in K ; i \in(I-\{0\}) ; j \in J$

5. Setiap konsumen hanya disuplai oleh satu gudang

$\sum_{k=1}^{k^{\prime}} \sum_{j=1}^{37} y_{i j}^{k} a_{i j} \leq x_{i}$ Cap untuk $i \in(I-\{0\})$

Kendala ini untuk memastikan konsumen $j$ tidak dapat dilayani dari $i$ kecuali gudang ditempatkan di $i$ dan setiap gudang akan menyuplai konsumen terdekat. 
6. Setiap konsumen hanya disuplai oleh satu kendaraan jenis $k$

$$
\begin{array}{ll}
\sum_{k=1}^{k^{\prime}} y_{0 i}^{k}=x_{i} & \text { untuk } i \in(I-\{0\}) \\
\sum_{i=1}^{n} \sum_{k=1}^{k^{\prime}} y_{i j}^{k}=1 & \text { untuk } j \in J
\end{array}
$$

7. Jumlah bahan ajar yang dikirim oleh gudang terpilih sama dengan jumlah permintaan seluruh konsumen yang dilayaninya

$\sum_{k=1}^{k^{\prime}} \sum_{j=1}^{37} y_{i j}^{k} a_{i j}=v_{i} \quad$ untuk $i \in(I-\{0\})$

Kendala ini untuk memastikan jumlah permintaan seluruh konsumen yang dilayani oleh setiap gudang terpilih terpenuhi.

8. Hubungan antara biaya transportasi dan jarak

$$
\begin{aligned}
c_{0 i}^{k} & =\gamma_{k} d_{0 i} \text { untuk } k \in K ; i \in(I-\{0\}) \\
c_{i j}^{k} & =\gamma_{k} d_{i j} \text { untuk } k \in K ; i \in(I-\{0\}) ; j \in J
\end{aligned}
$$

\section{Model III}

Diasumsikan stok bahan ajar di gudang terpilih tersedia sebanyak kapasitasnya.

Fungsi objektifnya adalah :

$$
\text { Minimumkan } \sum_{i=0}^{n} \sum_{j=1}^{37} \sum_{k=1}^{k^{\prime}} y_{i j}^{k} c_{i j}^{k} a_{i j}+\sum_{i=1}^{n} x_{i} f+\lambda \sum_{i=0}^{n}\left(x_{i} \operatorname{Cap}-v_{i}\right)
$$

\section{Batasan yang digunakan adalah :}

1. Satu kali pengiriman bahan ajar tidak lebih dari permintaan konsumen $w_{i j} M \geq q_{j}$ untuk $i \in I ; j \in J$

2. Pengiriman bahan ajar ke konsumen dilakukan minimal dua kali dalam setahun $w_{i j} \geq 2$ untuk $i \in I ; j \in J$

3. Jumlah bahan ajar yang disuplai sama dengan jumlah permintaan bahan ajar $w_{i j} a_{i j}=q_{j}$ untuk $i \in I ; j \in J$

4. Setiap gudang dan konsumen dapat dilayani dengan kendaraan jenis $k$ $y_{i j}^{k} a_{i j} \leq Q_{k}$ untuk $k \in K ; i \in I ; j \in J$

5. Setiap konsumen hanya disuplai oleh satu gudang 


$$
\sum_{k=1}^{k^{\prime}} \sum_{j=1}^{37} y_{i j}^{k} a_{i j} \leq x_{i} \text { Cap untuk } i \in I
$$

6. Setiap konsumen hanya disuplai oleh satu kendaraan jenis $k$

$$
\sum_{i=1}^{n} \sum_{k=1}^{k^{\prime}} y_{i j}^{k}=1 \quad \text { untuk } j \in J
$$

7. Jumlah bahan ajar yang dikirim oleh gudang terpilih sama dengan jumlah permintaan seluruh konsumen yang dilayaninya

$$
\sum_{k=1}^{k^{\prime}} \sum_{j=1}^{37} y_{i j}^{k} a_{i j}=v_{i} \quad \text { untuk } i \in I
$$

8. Hubungan antara biaya transportasi dan jarak

$$
c_{i j}^{k}=\gamma_{k} d_{i j} \text { untuk } k \in K ; i \in I ; j \in J
$$

\section{IMPLEMENTASI MODEL}

\section{Data Simulasi}

Simulasi dilakukan dengan menggunakan data koordinat geografi bumi, data perkiraan permintaan bahan ajar Pendas UT dan data biaya pengiriman berdasarkan subkontrak tahun 2008. Konstanta pengali $\left(\gamma_{k}\right)$ pada biaya transportasi ditentukan dengan metode Least Squares, dan diperoleh nilai $\gamma_{k}$ untuk kendaraan darat* 1,467 rupiah/km.kg ; trucking 9113 rupiah $/ \mathrm{km}$; laut 2,317 rupiah $/ \mathrm{km} . \mathrm{kg}$; udara 5,315 rupiah/ $/ \mathrm{km} . \mathrm{kg}$.

Dimisalkan kapasitas kendaraan jenis darat* maksimal 4.000 kilogram, trucking maksimal 8.000 kilogram, laut maksimal 8.000 kilogram dan udara maksimal 1.000 kilogram. Biaya penalti terhadap bahan ajar yang tersisa di gudang sebesar Rp. 5.000,- per kilogram. Jumlah minimal pengiriman bahan ajar setiap tahun 1.000 kilogram.

\section{Verifikasi Model}

Pada verifikasi ini akan digunakan data simulasi. Hasil yang diharapkan adalah apabila pada model II dan model III gudang terpilih tidak digunakan maka seluruh konsumen akan dilayani oleh gudang utama. Hal ini menunjukkan kedua model akan sama dengan model I. Dari hasil verifikasi, diperoleh bahwa model valid, biaya penggudangan di setiap gudang terpilih untuk satu kali pengiriman sebesar kapasitas 4.000 kilogram senilai Rp. 4.000.000,- dan kapasitas gudang di gudang utama sebesar 40.000 kilogram.

\section{Simulasi Model}

Setelah dilakukan pembandingan biaya distribusi dengan kapasitas gudang $4.000 ; 5.000$; $6.000 ; 7.000$; dan 8.000 kilogram, gudang dengan kapasitas 8.000 kilogram direkomendasikan sebagai solusi terbaik untuk model II dan III. 
Hasil simulasi model II menunjukkan bahwa gudang utama akan mengirimkan bahan ajar ke gudang terpilih menggunakan kendaraan jenis trucking. Gudang terpilih berada di Palembang, Jakarta, Bogor, Surakarta dan Majene. Gudang terpilih akan mengirimkan bahan ajar ke UPBJJ-UT yang dilayani menggunakan kendaraan jenis darat*. UPBJJ-UT yang dilayani oleh setiap gudang terpilih itu adalah :

- Gudang terpilih Palembang melayani UPBJJ-UT Banda Aceh, Medan, Batam, Padang, Pekanbaru, Jambi, Palembang dan Bengkulu.

- Gudang terpilih Jakarta melayani UPBJJ-UT Pangkal Pinang, Bandar Lampung, Jakarta, Pontianak, Palangkaraya, Banjarmasin, Samarinda dan Ternate.

- Gudang terpilih Bogor melayani UPBJJ-UT Serang, Bogor, Bandung, Purwokerto dan Semarang.

- Gudang terpilih Surakarta melayani UPBJJ-UT Surakarta, Yogyakarta, Surabaya, Malang, Jember, Denpasar, Mataram dan Kupang.

- Gudang terpilih Majene melayani UPBJJ-UT Makassar, Majene, Palu, Kendari, Manado, Gorontalo, Ambon dan Jayapura.

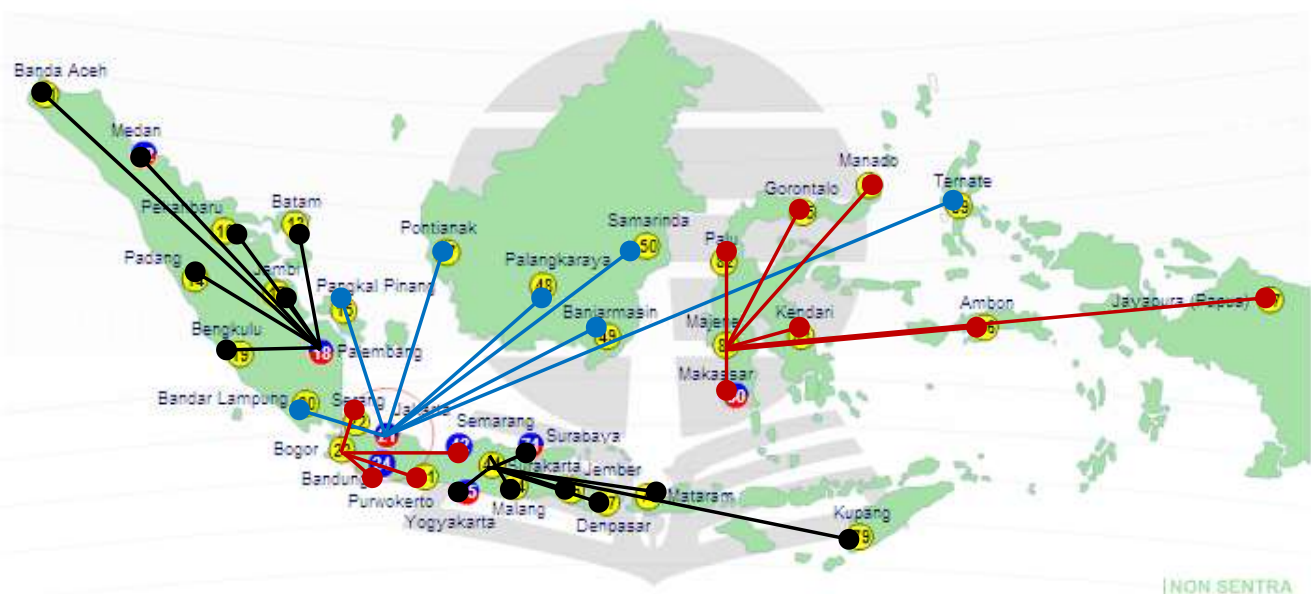

Gambar 1. Lokasi gudang terpilih dan UPBJJ-UT yang dilayaninya pada sistem distribusi bahan ajar tidak terpusat alternatif 1 .

Hasil simulasi model III menunjukkan bahwa gudang terpilih berada di Pekanbaru, Jakarta, Malang, Majene dan Ternate. Gudang terpilih akan mengirimkan bahan ajar ke UPBJJ-UT yang dilayani menggunakan kendaraan jenis darat*. UPBJJ-UT yang dilayani oleh setiap gudang terpilih itu adalah :

- Gudang terpilih Pekanbaru melayani UPBJJ-UT Banda Aceh, Medan, Batam, Padang, Pekanbaru, Jambi, Palembang dan Bengkulu.

- Gudang terpilih Jakarta melayani UPBJJ-UT Pangkal Pinang, Bandar Lampung, Jakarta, Serang, Bogor, Bandung, Purwokerto dan Pontianak.

- Gudang terpilih Malang melayani UPBJJ-UT Semarang, Surakarta, Yogyakarta, Surabaya, Malang, Jember, Denpasar dan Mataram. 
- Gudang terpilih Majene melayani UPBJJ-UT Palangkaraya, Banjarmasin, Samarinda, Kupang, Makassar, Majene, Palu dan Kendari.

- Gudang terpilih Ternate melayani UPBJJ-UT Manado, Gorontalo, Ambon, Jayapura dan Ternate.

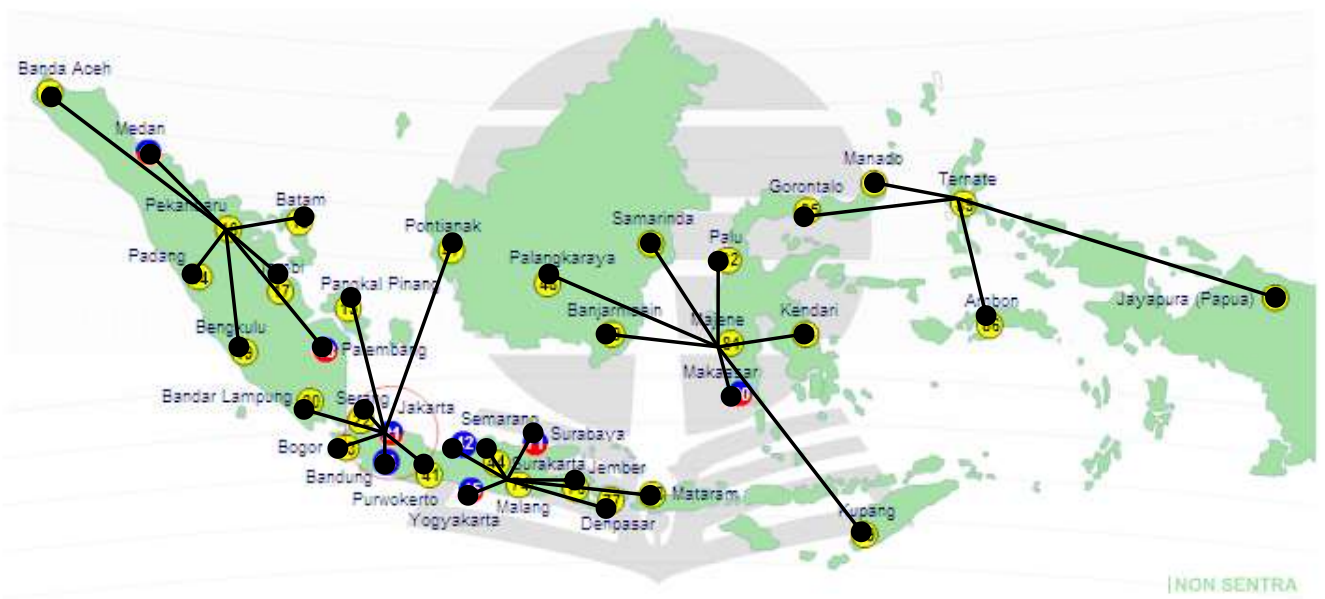

Gambar 2. Lokasi gudang terpilih dan UPBJJ-UT yang dilayaninya pada sistem distribusi bahan ajar tidak terpusat alternatif 2 .

\section{Analisis Masalah Distribusi Bahan Ajar Universitas Terbuka Berdasarkan Hasil Simulasi}

Dimisalkan, biaya percetakan di gudang utama senilai Rp. 4.000,- dan di gudang terpilih Rp. 5.000 ,- per kilogram. Biaya penggudangan di gudang utama untuk satu kali pengiriman sebesar kapasitas 40.000 kilogram senilai Rp 20.000.000,-.

Tabel 1. Hasil Keseluruhan Simulasi Ketiga Model

\begin{tabular}{lccc}
\hline Model & $\begin{array}{c}\text { Jumlah biaya pengiriman } \\
\text { dari gudang ke } \\
\text { konsumen } \\
\text { (rupiah) }\end{array}$ & $\begin{array}{c}\text { Biaya distribusi untuk } \\
\text { satu kali pengiriman } \\
\text { (rupiah) }\end{array}$ & $\begin{array}{c}\text { Total biaya operasional } \\
\text { untuk satu kali pengiriman } \\
\text { (rupiah) }\end{array}$ \\
\hline Model I & 55.980 .710 & 73.768 .160 & 253.768 .160 \\
Model II & 51.810 .040 & 89.597 .490 & 269.597 .490 \\
Model III & 18.757 .090 & 56.544 .540 & 256.544 .540 \\
\hline
\end{tabular}

Ketiga model disusun untuk menentukan biaya distribusi minimal dalam satu tahun, hal ini dikarenakan tolok ukur dari penyusunan model II dan III adalah pemilihan gudang. Dalam hal ini, untuk membandingkan efisiensi ketiga model dilihat dari jumlah biaya pengiriman dari gudang ke konsumen. Selain itu dilihat pula total biaya operasional yaitu penjumlahan dari biaya distribusi, biaya penggudangan di gudang utama dan biaya percetakan di setiap gudang.

Berdasarkan Tabel 1, jika jumlah permintaan seluruh konsumen merupakan jumlah minimal pengiriman dalam satu tahun maka total biaya operasional sistem distribusi bahan ajar terpusat paling minimal, sehingga sistem distribusi bahan ajar tidak terpusat alternatif 1 dan 2 tidak menguntungkan bagi UT. 
Analisis Masalah Distribusi Bahan Ajar Universitas Terbuka Berdasarkan Total Biaya Operasional

Pada Tabel 2 diperlihatkan perbandingan antar model berdasarkan total biaya operasional untuk keseluruhan permintaan UPBJJ-UT tahun 2008. Pada total biaya operasional berikut, dimisalkan untuk setiap kenaikan permintaan UPBJJ-UT diberikan maksimal permintaan setiap UPBJJ-UT sebesar 100.000 kilogram dalam satu tahun.

Tabel 2. Perbandingan Kenaikan Permintaan Konsumen terhadap Total Biaya Operasional pada Ketiga Model

\begin{tabular}{|c|c|c|c|}
\hline \multirow[b]{2}{*}{ Model } & \multicolumn{3}{|c|}{ Total biaya operasional (rupiah) } \\
\hline & $\begin{array}{c}\text { Permintaan tahun } \\
2008 \\
\end{array}$ & $\begin{array}{l}2 \times \text { Permintaan } \\
\text { tahun } 2008\end{array}$ & $\begin{array}{l}3 \times \text { Permintaan } \\
\text { tahun } 2008\end{array}$ \\
\hline Model I & 2.688 .089 .559 & 4.788 .713 .049 & 6.461 .662 .485 \\
\hline Model II & 2.828 .092 .455 & 5.037 .115 .606 & 6.807.916.919 \\
\hline Model III & 2.546.472.994 & 4.543.326.346 & 6.179 .556 .029 \\
\hline
\end{tabular}

Pada Tabel 2 terlihat bahwa total biaya operasional model III lebih kecil daripada model I untuk seluruh permintaan bahan ajar tahun 2008. Total biaya operasional model II akan selalu lebih besar dibandingkan model I, disebabkan biaya distribusi pada model II lebih besar daripada model I dan adanya biaya penggudangan di gudang terpilih pada model II. Selain itu, terlihat bahwa jika permintaan bahan ajar meningkat sebanyak kelipatan jumlah permintaan bahan ajar tahun 2008 maka total biaya operasional model III paling kecil dibandingkan model yang lain.

Berdasarkan hasil perhitungan pada Tabel 2, berikut akan diperlihatkan grafik dari setiap komponen total biaya operasional, sehingga akan diketahui faktor-faktor yang mempengaruhi perbedaan biaya setiap model.

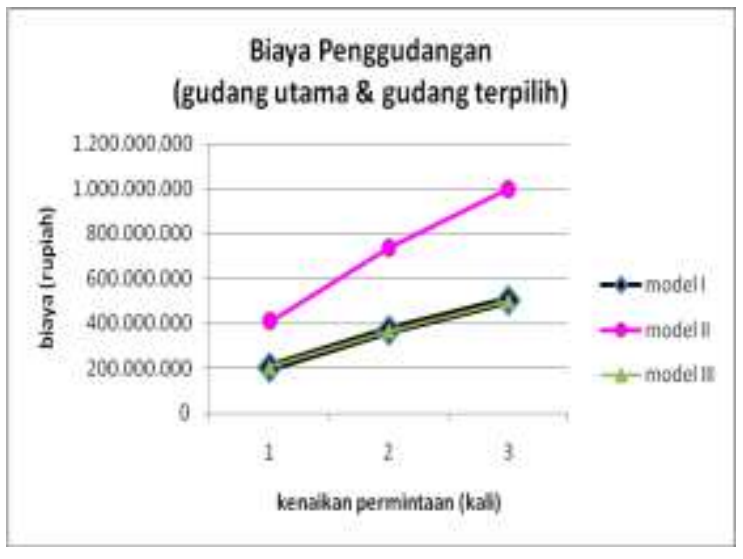

Gambar 4. Grafik perbandingan biaya penggudangan ketiga model

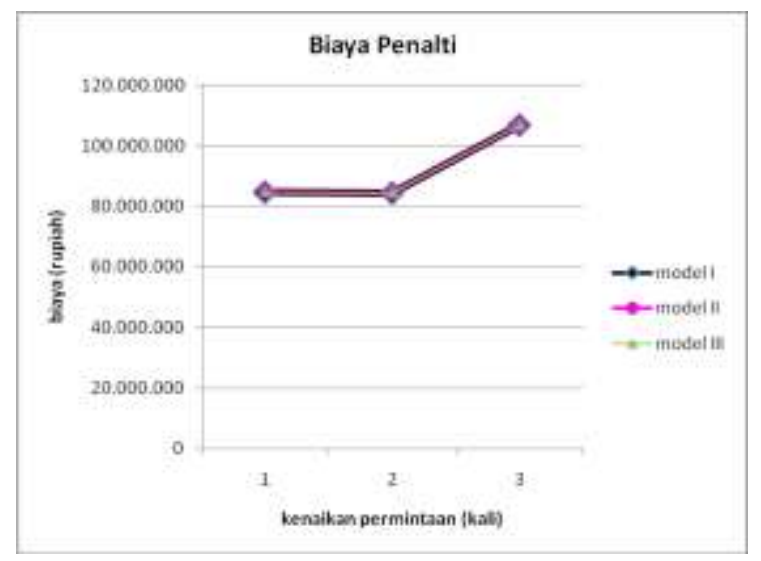

Gambar 5. Grafik perbandingan biaya penalti ketiga model 


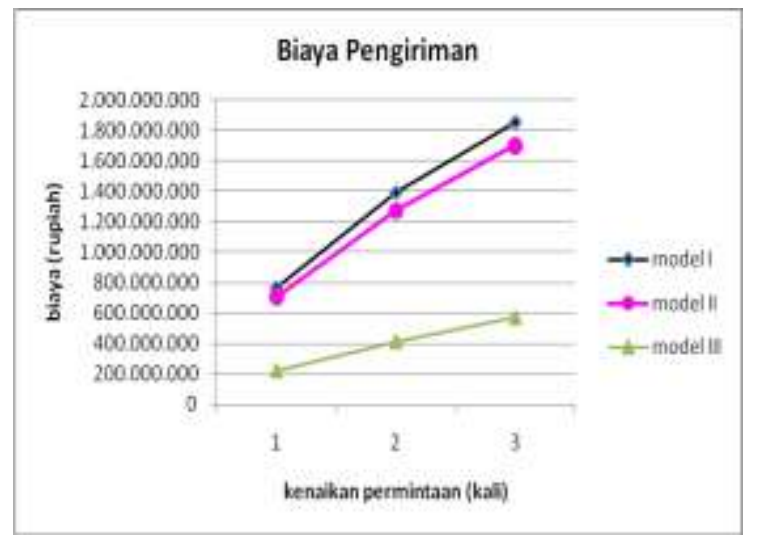

Gambar 6. Grafik perbandingan biaya pengiriman ketiga model

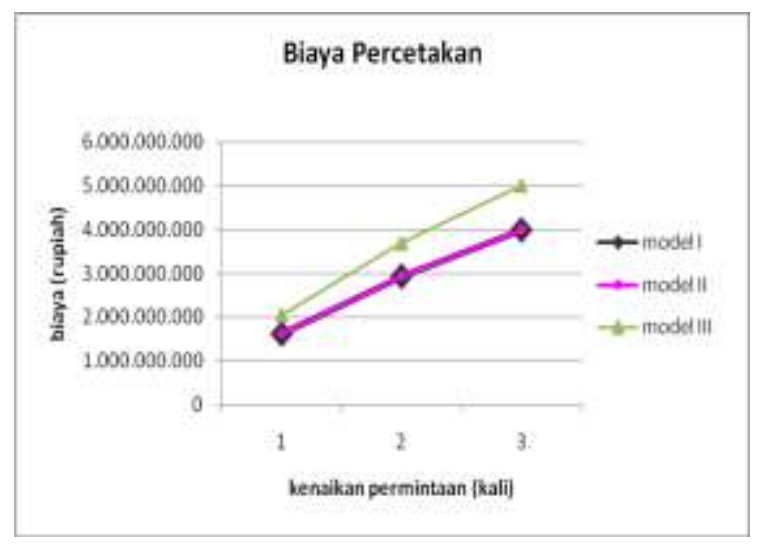

Gambar 7. Grafik perbandingan biaya percetakan ketiga model

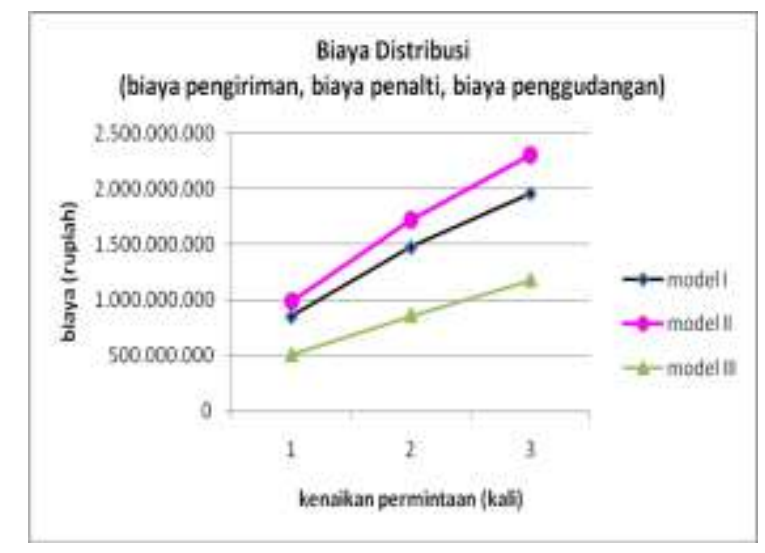

Gambar 8. Grafik perbandingan biaya distribusi ketiga model

Dari Gambar 4 sampai dengan Gambar 7, dapat dinyatakan bahwa kenaikan setiap komponen biaya pada total biaya operasional sebanding dengan kenaikan permintaan bahan ajar.

\section{KESIMPULAN}

Sistem distribusi bahan ajar tidak terpusat yang menempatkan gudang antara Kantor Pusat UT dengan UPBJJ-UT ada dua macam, yaitu sistem distribusi bahan ajar tidak terpusat alternatif 1 dan sistem distribusi bahan ajar tidak terpusat alternatif 2 . Kedua sistem tersebut dimodelkan menjadi model II dan model III. 
Simulasi model II menunjukkan bahwa gudang terpilih ditempatkan di Palembang, Jakarta, Bogor, Surakarta dan Majene.

- Gudang terpilih Palembang melayani UPBJJ-UT Banda Aceh, Medan, Batam, Padang, Pekanbaru, Jambi, Palembang dan Bengkulu.

- Gudang terpilih Jakarta melayani UPBJJ-UT Pangkal Pinang, Bandar Lampung, Jakarta, Pontianak, Palangkaraya, Banjarmasin, Samarinda dan Ternate.

- Gudang terpilih Bogor melayani UPBJJ-UT Serang, Bogor, Bandung, Purwokerto dan Semarang.

- Gudang terpilih Surakarta melayani UPBJJ-UT Surakarta, Yogyakarta, Surabaya, Malang, Jember, Denpasar, Mataram dan Kupang.

- Gudang terpilih Majene melayani UPBJJ-UT Makassar, Majene, Palu, Kendari, Manado, Gorontalo, Ambon dan Jayapura.

Simulasi model III menempatkan gudang terpilih di Pekanbaru, Jakarta, Malang, Majene dan Ternate.

- Gudang terpilih Pekanbaru melayani UPBJJ-UT Banda Aceh, Medan, Batam, Padang, Pekanbaru, Jambi, Palembang dan Bengkulu.

- Gudang terpilih Jakarta melayani UPBJJ-UT Pangkal Pinang, Bandar Lampung, Jakarta, Serang, Bogor, Bandung, Purwokerto dan Pontianak.

- Gudang terpilih Malang melayani UPBJJ-UT Semarang, Surakarta, Yogyakarta, Surabaya, Malang, Jember, Denpasar dan Mataram.

- Gudang terpilih Majene melayani UPBJJ-UT Palangkaraya, Banjarmasin, Samarinda, Kupang, Makassar, Majene, Palu dan Kendari.

- Gudang terpilih Ternate melayani UPBJJ-UT Manado, Gorontalo, Ambon, Jayapura dan Ternate.

Selain itu, hasil simulasi menunjukkan bahwa sistem distribusi bahan ajar terpusat merupakan sistem yang total biaya operasionalnya lebih murah dibandingkan dengan sistem distribusi bahan ajar tidak terpusat yang diusulkan jika permintaan bahan ajar setiap konsumen merupakan jumlah minimal pengiriman dalam satu tahun. Namun untuk keseluruhan permintaan bahan ajar tahun 2008 dan kelipatan kenaikannya, sistem distribusi bahan ajar tidak terpusat alternatif 2, yaitu sistem yang menempatkan percetakan dan gudang di UPBJJ-UT terpilih untuk melayani UPBJJ-UT terdekat, lebih efisien daripada sistem distribusi bahan ajar terpusat.

\section{REFERENSI}

Chang, K.T. (2004). Geographic information system. New York: The McGraw-Hill Companies inc. Kotler, P., Ang, H.S., Leong, M.S., \& Tan, T.C. (2002). Manajemen pemasaran perspektif Asia Buku 2. (1sted). Handoyo P \& Hamin, penerjemah. Yogyakarta : Andi Offset.

Pratmoko, A. (2002). Sistem distribusi bahan ajar Universitas Terbuka menggunakan metode simpleks transportasi (Tinjauan Alternatif). Jurnal Matematika, Sains dan Teknologi 3 ; 1-10 Sitta, A. (2009). Model distribusi bahan ajar Universitas Terbuka dan implementasinya. Tesis Master yang tidak dipublikasikan, Institut Pertanian Bogor, Bogor. 